\title{
Ovicides paralithodis (Nemertea, Carcinonemertidae), a new species of symbiotic egg predator of the red king crab Paralithodes camtschaticus (Tilesius, I8 I5) (Decapoda, Anomura)
}

\author{
Hiroshi Kajihara ${ }^{1, \dagger}$, Armand M. Kuris ${ }^{2,+}$ \\ I Faculty of Science, Hokkaido University, Sapporo 060-0810, Japan 2 Marine Science Institute \& Department \\ of Ecology, Evolution and Marine Biology, University of California, Santa Barbara, CA 93106-9610, USA \\ † urn:lsid:zoobank.org:author:D43FC916-850B-4F35-A78C-C2116447C606 \\ $\ddagger$ urn:lsid:zoobank.org:author:DEF44B3D-F5AF-47DC-8F4A-CF4EB3F54D4C \\ Corresponding author: Hiroshi Kajihara (kazi@mail.sci.hokudai.ac.jp)
}

Academic editor:Jon Norenburg | Received 7 November 2012 | Accepted 7 January 2013 | Published 14 January 2013

urn:lsid:zoobank.org:pub:B0271AE6-3E1D-4C76-81FD-54242FAE4A5D

Citation: Kajihara H, Kuris AM (2013) Ovicides paralithodis (Nemertea, Carcinonemertidae), a new species of symbiotic egg predator of the red king crab Paralithodes camtschaticus (Tilesius, 1815) (Decapoda, Anomura). ZooKeys 258: 1-15. doi: $10.3897 /$ zookeys. 258.4260

\begin{abstract}
Ovicides paralithodis sp. n. is described from the egg mass of the red king crab Paralithodes camtschaticus (Tilesius, 1815) from the Sea of Okhotsk, off Hokkaido, Japan, and Alaska, USA. Among four congeners, O. paralithodis can be distinguished from O. julieae Shields, 2001 and O. davidi Shields and Segonzac, 2007 by having no eyes; from $O$. jonesi Shields and Segonzac, 2007 by the presence of basophilic, vacuolated glandular lobes in the precerebral region; and from O. jasoni Shields and Segonzac, 2007 by the arrangement of the acidophilic submuscular glands, which are not arranged in a row. Ovicides paralithodis represents the third described species of egg-predatory nemertean from $P$. camtschaticus, the second described carcinonemertid species from Japan, and the 21st described species in the family. The intensity of infestations may exceed 24,000 worms per a single egg-bearing pleopod of $P$. camtschaticus. A preliminary molecular phylogenetic analysis based on sequences of $28 \mathrm{~S}$ rRNA and cytochrome $c$ oxidase subunit I genes among selected monostiliferous hoplonemertean species supported the monophyly of Carcinonemertidae, suggesting that within the lineage of the family, evolution of the unique vas deferens, Takakura's duct, preceded loss of accessory stylets and accessory-stylet pouches.
\end{abstract}

\section{Keywords}

Nemertini, Crustacea, Paralithodes camtschatica, symbiont, egg predator

Copyright Hiroshi Kajihara,Armand M. Kuris. This is an open access article distributed under the terms of the Creative Commons Attribution License 3.0 (CC-BY), which permits unrestricted use, distribution, and reproduction in any medium, provided the original author and source are credited. 


\section{Introduction}

Nemerteans in the monostiliferous hoplonemertean family Carcinonemertidae are ectosymbiont egg predators of decapod crustacean hosts (Humes 1942, Jensen and Sadeghian 2005). The family is comprised of two genera, Carcinonemertes Coe, 1902 and Ovicides Shields, 2001, each containing 16 (Sadeghian and Santos 2010) and four (Shields and Segonzac 2007) species, respectively. They are known from approximately 70 host species (Sadeghian and Santos 2010), but the actual diversity of carcinonemertids is likely to be much greater (Kuris 1993). Crustacean-egg predatory nemerteans other than Carcinonemertidae include Alaxinus oclairi Gibson, Wickham and Kuris, 1990 and Pseudocarcinonemertes homari Fleming and Gibson, 1981.

The red king crab, Paralithodes camtschaticus (Tilesius, 1815), is a commercially important anomuran decapod, native to the Bering Sea, the Sea of Japan, the Sea of Okhotsk, and the North Pacific from the Kamchatka Peninsula to Alaska. Wickham and Kuris (1985) listed three undescribed species of egg-predator nemerteans on $P$. camtschaticus in Alaska, and Wickham and Kuris (1988) recognized five undescribed forms. Later, Forms 1 and 2 sensu Wickham and Kuris (1988) were respectively described as $C$. regicides Shields, Wickham and Kuris, 1989 and A. oclairi, while Forms 3-5 remained undescribed.

A survey of egg masses of $P$. camtschaticus in Hokkaido, northern Japan, yielded specimens that correspond to Form 4 of Wickham and Kuris (1988) from Alaska, which is herein described as a new species belonging to Ovicides.

\section{Methods}

Twenty female specimens of the red king crab $P$. camtschaticus were obtained in the Sea of Okhotsk, off Abashiri, Hokkaido, Japan, at $44^{\circ} 06^{\prime} \mathrm{N}, 144^{\circ} 32^{\prime} \mathrm{E}$, from $215 \mathrm{~m}$ in depth, by crab cages set from 28 November 2011 to 15 December 2011. Of these female crabs, 16 were ovigerous, from three of which we procured a single nemertean specimen. The worms were anaesthetized in $\mathrm{MgCl}_{2}$ solution isotonic to seawater. The anterior halves of the worms were fixed in Bouin's solution for histological preparation; the posterior halves were preserved in $99 \%$ ethanol for DNA extraction. Histological preparation follows that of Kajihara et al. (2011a, b). The type slides are deposited in the Hokkaido University Museum, Sapporo, Japan (ZIHU).

DNA extraction, PCR amplification, and sequencing of the nuclear 28S rRNA gene and mitochondrial cytochrome $c$ oxidase subunit I gene (COI) largely follow those of Kajihara et al. (2011a, b). Sequences from the holotype, the egg strand laid by the holotype, and the allotype were exactly the same $(p=0.0)$, with respect to both $28 \mathrm{~S}$ rRNA (1141 bp) and COI (658 bp).

A preliminary analysis was carried out to assess the phylogenetic affinities of the new species, including 16 species of Distromatonemertea, in addition to two outgroup species, for which $28 \mathrm{~S}$ rRNA and COI sequences were available in GenBank 
(Table 1). Alignment of the sequences was carried out by MUSCLE (Edgar 2004a, b) implemented in MEGA ver. 5.05 (Tamura et al. 2011). Model selection and a maximum likelihood analysis using nearest-neighbour interchange tree rearrangement in heuristic search were also performed by MEGA ver. 5.05 (Tamura et al. 2011), based on the general time-reversible model (Tavaré 1986) with gamma-distributed rate heterogeneity and a proportion of invariant sites $(G T R+G+I)$ selected by Akaike Information Criterion (Akaike 1974) as the best-fit substitution model; a bootstrap analysis (Felsenstein 1985) with 1000 replications was performed to evaluate nodal supports. The concatenated matrix of $28 \mathrm{~S}$ rRNA and COI sequences comprised 1851 bp (excluding gap positions) after alignment of each submatrix.

Observations on abundance and geographic distribution in Alaska were conducted from 1983 to 1985, as described in Kuris et al. (1991). Observations of living specimens were made on worms from red king crabs collected near Homer, Seward and Juneau, Alaska.

Table I. List of species included in the phylogenetic analysis, with GenBank accession numbers.

\begin{tabular}{|c|c|c|c|}
\hline Species & $28 S$ rRNA & COI & Sources \\
\hline Amphiporus imparispinosus Griffin, 1898 & HQ856878 & HQ848612 & Andrade et al. (2012) \\
\hline Amphiporus lactifloreus (Johnston, 1828) & HQ856876 & HQ848611 & Andrade et al. (2012) \\
\hline Antarctonemertes varvarae Chernyshev, 1999 & AJ436845 & AJ436900 & $\begin{array}{l}\text { Thollesson and } \\
\text { Norenburg (2003) }\end{array}$ \\
\hline Argonemertes australiensis (Dendy, 1892) & HQ856892 & HQ848601 & Andrade et al. (2012) \\
\hline Carcinonemertes carcinophila (Kölliker, 1845) & HQ856893 & HQ848619 & Andrade et al. (2012) \\
\hline $\begin{array}{l}\text { Carcinonemertes cf. carcinophila imminuta } \\
\text { Humes, } 1942\end{array}$ & AJ436846 & AJ436901 & $\begin{array}{l}\text { Thollesson and } \\
\text { Norenburg (2003) }\end{array}$ \\
\hline Emplectonema gracile (Johnston, 1837) & HQ856883 & HQ848620 & Andrade et al. (2012) \\
\hline Gononemertes parasita Bergendal, 1900 & HQ856889 & HQ848607 & Andrade et al. (2012) \\
\hline Leptonemertes chalicophora (Graff, 1879) & HQ856898 & HQ848596 & Andrade et al. (2012) \\
\hline Nemertellina yamaokai Kajihara et al., 2000 & AJ436852 & AJ436907 & $\begin{array}{l}\text { Thollesson and } \\
\text { Norenburg (2003) }\end{array}$ \\
\hline Oerstedia dorsalis (Abildgaard, 1806) & AY210465 & AY791971 & $\begin{array}{c}\text { Thollesson and } \\
\text { Norenburg (2003) }\end{array}$ \\
\hline Oerstedia venusta Iwata, 1954 & AJ436856 & AJ436911 & $\begin{array}{l}\text { Thollesson and } \\
\text { Norenburg (2003) }\end{array}$ \\
\hline Ovicides paralithodis sp. $\mathrm{n}$. & $\mathrm{AB} 704416$ & $\mathrm{AB} 704417$ & Present study \\
\hline Paranemertes peregrina Coe, 1901 & AJ436860 & AJ436915 & $\begin{array}{l}\text { Thollesson and } \\
\text { Norenburg (2003) }\end{array}$ \\
\hline Paranemertes sanjuanensis Stricker, 1982 & AJ436862 & AJ436917 & $\begin{array}{l}\text { Thollesson and } \\
\text { Norenburg (2003) }\end{array}$ \\
\hline Zygonemertes simoneae Corrêa, 1961 & AJ436867 & AJ436922 & $\begin{array}{l}\text { Thollesson and } \\
\text { Norenburg (2003) }\end{array}$ \\
\hline Zygonemertes virescens (Verrill, 1879) & AJ436868 & AJ436923 & $\begin{array}{l}\text { Thollesson and } \\
\text { Norenburg (2003) }\end{array}$ \\
\hline \multicolumn{4}{|l|}{ Outgroups } \\
\hline Nipponnemertes punctatula (Coe, 1905) & AJ436855 & AJ436910 & $\begin{array}{l}\text { Thollesson and } \\
\text { Norenburg (2003) }\end{array}$ \\
\hline Paradrepanophorus crassus (Quatrefages, 1846) & HQ856867 & HQ848603 & Andrade et al. (2012) \\
\hline
\end{tabular}




\section{Results}

\section{Ovicides paralithodis sp. $\mathbf{n}$.}

urn:Isid:zoobank.org:act:1E52DC7A-C52F-4502-AEAC-7A3EB0244F4D

http://species-id.net/wiki/Ovicides_paralithodis

Figs $1-5$

Carcinonemertidae Form 4: Wickham and Kuris (1988).

Material examined. Holotype: female, ZIHU 4271, serial transverse sections $(8 \mu \mathrm{m}$ thick) of anterior body fragment, stained with Mallory's trichrome method, 5 slides. Allotype: male, ZIHU 4272, serial transverse sections ( $8 \mu \mathrm{m}$ thick) of anterior body fragment, stained with Mallory's trichrome method, 3 slides. The other specimen obtained (female) was destroyed and lost during preparation.

Diagnosis. An Ovicides without eyes; vacuolated, basophilic glandular lobes extending pre- and post-cerebrally; acidophilic submuscular glands scattered among basophilic lobes, not arranged in row; sexes separate; female and male about $1 \mathrm{~cm}$ and 5 $\mathrm{mm}$ in length, respectively.

Type host. Paralithodes camtschaticus (Tilesius, 1815) (Decapoda, Anomura).

Description. External features. In life, holotype (female) about $1 \mathrm{~cm}$ long, $0.9 \mathrm{~mm}$ wide; pale orange in colour (largely due to alimentary canal), except whitish tip of head (Fig 1A). Allotype (male) about $5 \mathrm{~mm}$ in length, $0.3 \mathrm{~mm}$ in width; cream white in colour (Fig. 1B). Living in thin, transparent mucous tube.

Proboscis apparatus. Rhynchodaeum opening to dorsal wall of oesophagus (Fig. $2 \mathrm{~A})$. Anterior proboscis chamber $136 \mu \mathrm{m}$ (unknown in allotype) long by $100 \mu \mathrm{m}(82$ $\mu \mathrm{m}$ in allotype) diameter; central stylet basis $48 \mu \mathrm{m}$ (56 $\mu \mathrm{m}$ in allotype) long by $20 \mu \mathrm{m}$ (20 $\mu \mathrm{m}$ in allotype) diameter (Figs $2 \mathrm{~B}, 3)$; central stylet $16 \mu \mathrm{m}$ (12 $\mu \mathrm{m}$ in allotype) in length (all measured from transverse sections); stylet to basis ratio $0.21-0.33$; two accessory stylet pouches each containing two accessory stylets (Fig. 2C). Middle proboscis chamber $80 \mu \mathrm{m}(54 \mu \mathrm{m}$ in allotype) in diameter. Posterior proboscis chamber 240 $\mu \mathrm{m}$ (unknown in allotype) long by $130 \mu \mathrm{m}$ (94 $\mu \mathrm{m}$ in allotype) wide. Proboscis almost same length as rhynchocoel, extending posteriorly behind pylorus-intestine junction; musculature of rhynchocoel wall uncertain in light microscopy.

Alimentary canal. Oesophagus opening ventrally at tip of head. Stomach wall containing circular muscle fibres (Fig. 2D).

Glandular system. Vacuolated, basophilic glandular lobes filling much space of precerebral region between body-wall musculature and oesophagus (Fig. 2A), extending post-cerebrally in intestinal region, but gradually less distinct posteriorly (Fig. 4A). Acidophilic submuscular glands scattered among basophilic lobes (Fig. 2A), not arranged in row beneath body-wall musculature.

Excretory system. Flame cells, nephridioducts, and nephridiopores not found.

Nervous system. Dorsal and ventral brain commissures $13 \mu \mathrm{m}(9 \mu \mathrm{m}$ in allotype) and $10 \mu \mathrm{m}$ (7 $\mu \mathrm{m}$ in allotype) in thickness, respectively (Fig. 3). 


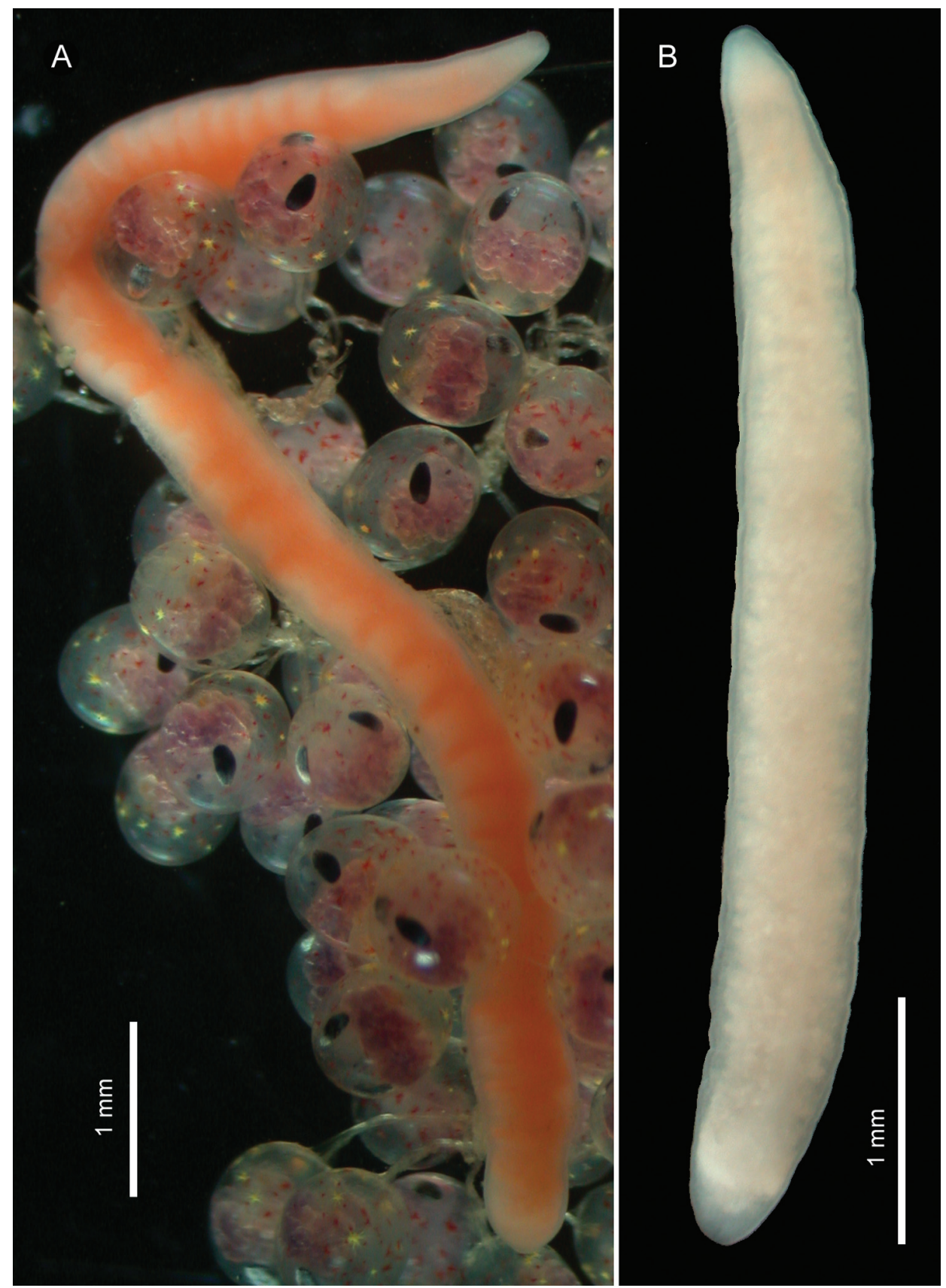

Figure I. Ovicides paralithodis sp. n., photographs taken in life. A holotype, female, ZIHU 4271 B allotype, male, ZIHU 4272.

Vascular system. Pair of cephalic vessels meeting above rhynchodaeum, posteriorly passing through cerebral ring (Fig. 3), extending further backward as lateral vessel on each side, situated near lateral nerve cord (Fig. 4A). 


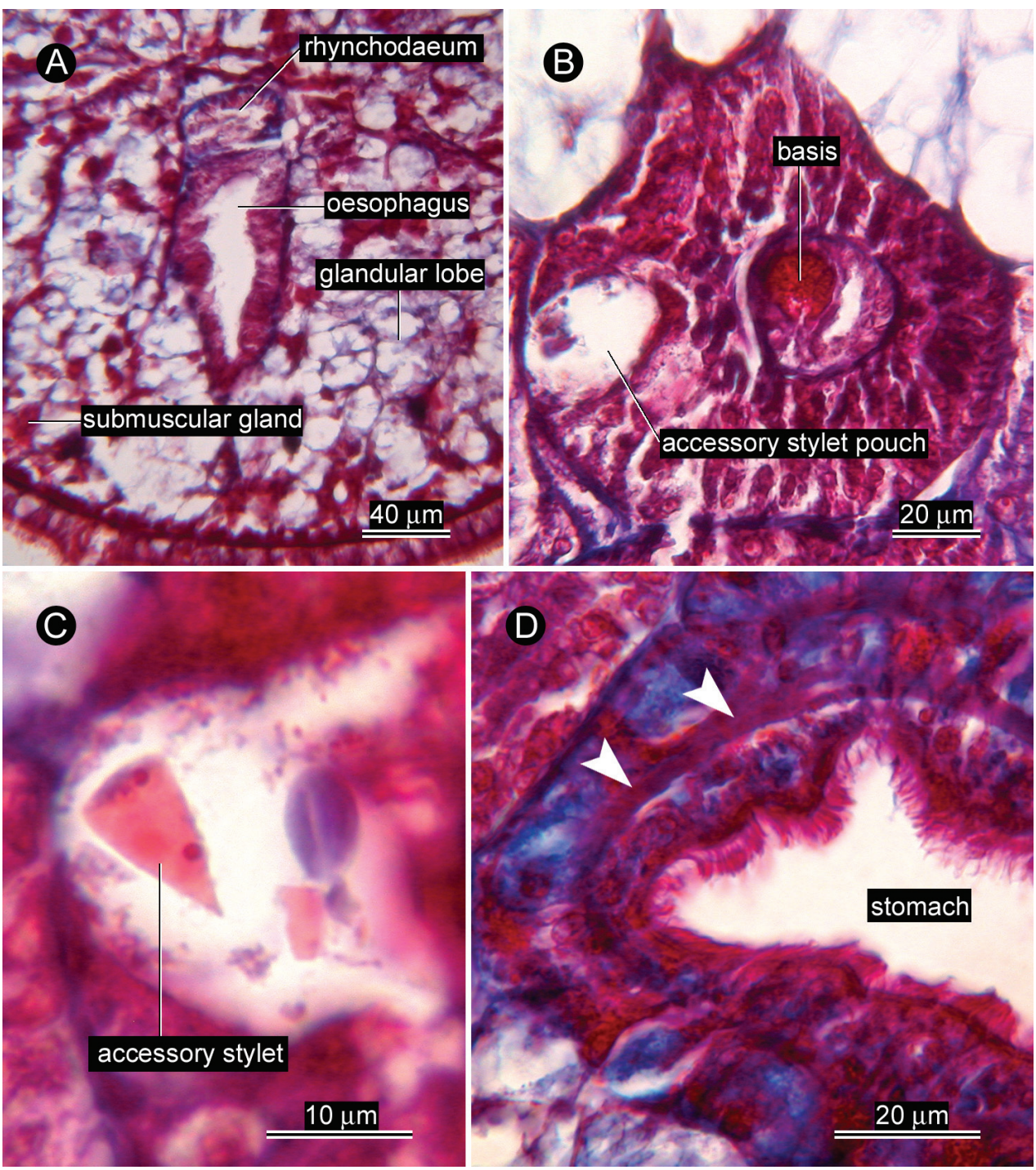

Figure 2. Ovicides paralithodis sp. n., photomicrographs of transverse sections. A precerebral region, showing rhynchodaeum just after branched off from oesophagus B anterior proboscis chamber showing stylet basis and one of the two accessory stylet pouches $\mathbf{C}$ accessory stylet $\mathbf{D}$ stomach, showing circular muscle fibres (indicated by arrowheads). A, C, D, allotype, male, ZIHU 4272; B, holotype, female, ZIHU 4271.

Sensory system. No eyes. No cerebral organs. No frontal organ.

Reproductive system. Ovaries more or less regularly interspersed with intestinal lateral diverticula, arranged in row on each side of body; single oviduct from each ovary extending dorsally (Fig. 4B). Single egg string found in the same crab egg mass about $1 \mathrm{~cm}$ in length, containing pink eggs (Fig. 5A, B). Takakura's duct present in male, about $40 \mu \mathrm{m}$ in diameter (Fig. 4A). 


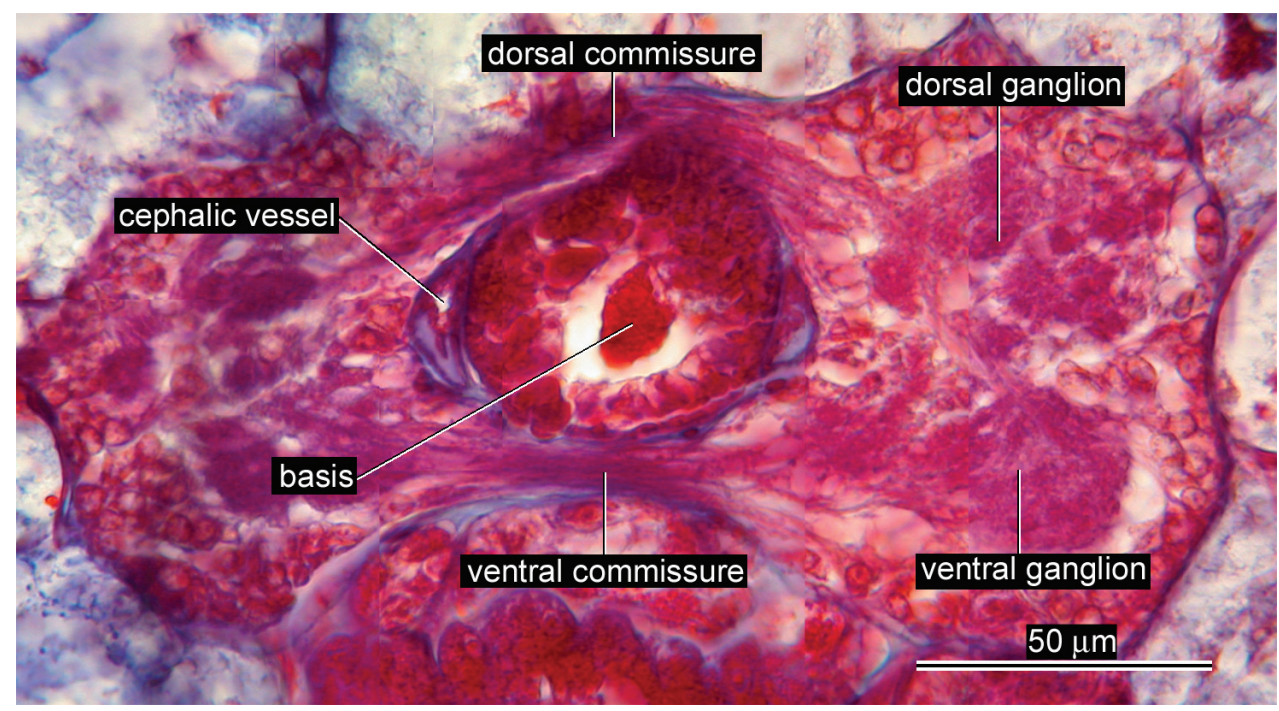

Figure 3. Ovicides paralithodis sp. n., photomicrograph of transverse section through brain ring, allotype, male, ZIHU 4272.

Behaviour. Fed on P. camtschaticus eggs in vitro, piercing the egg membrane with its stylet and consuming the contents of the ruptured eggs. In vivo feeding confirmed by frequent observations of gut contents containing crab egg yolk and eye placodes. Juvenile worms were recovered from two of 30 male and non-ovigerous female crabs collected at Juneau and Seward, Alaska. The presence of juvenile worms on hosts lacking eggs suggests that the life cycle of Ovicides paralithodis may be more similar to carcinonemertids such as Carcinonemertes errans Wickham, 1978 where worms can transfer from males to females, and from premoult to postmoult cuticles of non-ovigerous crabs (Wickham et al. 1984, Kuris 1993) than to C. regicides of the red king crab for which transmission only occurs among brooding female crabs (Kuris et al. 1991). A life cycle involving non-ovigerous hosts may be common among Ovicides spp. since Shields and Segonzac (2007) described the other known species of Ovicides from non-ovigerous crabs.

Ecology. The proportion of infested crabs exceeded 50 percent at 13 localities in Alaska, reaching 100 percent at five localities. At six localities the intensity of infestations exceeded 1,000 worms per pleopod (red king crabs have six egg-bearing pleopods), with the highest reported intensity at Terror Bay, Kodiak Island, >24,000 worms per pleopod (Kuris et al. 1991) (voucher specimens are deposited in the Santa Barbara Museum of Natural History, CA, USA). At most locations sampled in Alaska it co-occurred with Carcinonemertes regicides, but it was usually less abundant than $C$. regicides. It was the only symbiotic egg predator nemertean present on red king crabs along the Alaska Peninsula and it was rare at Cook Inlet where C. regicides caused up to $95 \%$ brood mortality.

Etymology. The specific name, paralithodis, is a noun in the genitive case, derived from the generic name of the host crustacean, Paralithodes camtschaticus. 


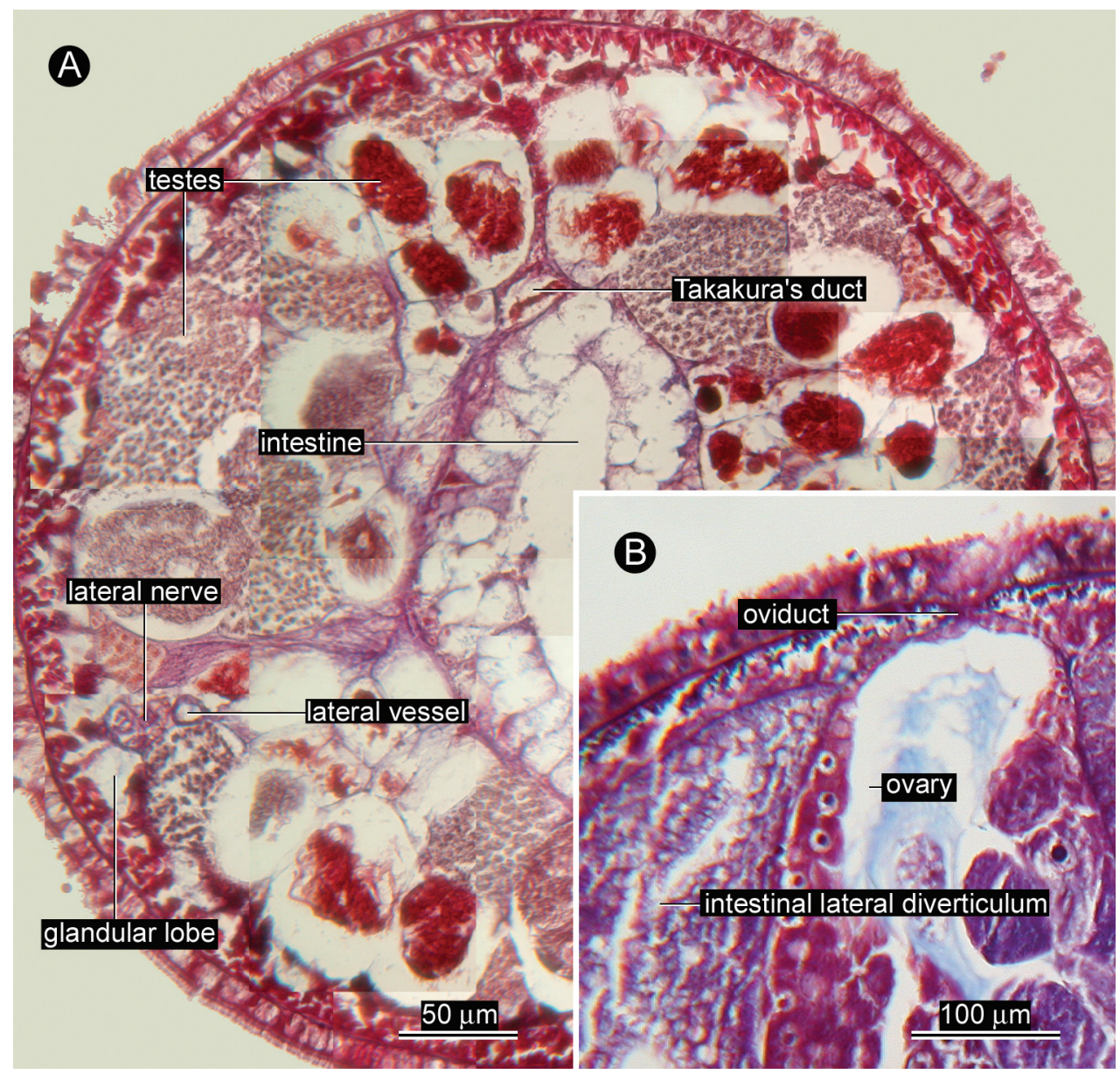

Figure 4. Ovicides paralithodis sp. n., photomicrographs of transverse sections through intestinal region. A testes and Takakura's duct, allotype, male, ZIHU 4272 B gonopore opening dorsally, holotype, female, ZIHU 4271.

Distribution. In addition to the type locality, the Sea of Okhotsk, off Abashiri, Hokkaido, Japan, O. paralithodis has been reported from Adak, Dutch Harbor, Morshovoi Bay, Pavlof Bay, Kodiak Island, Resurrection Bay, Seward, Cook Inlet and Southeastern Alaska (Barlow Cove, Deadman's Reach, Gambier Cove, and Pybus Cove, Juneau) by Kuris et al. (1991) as Form 4. The distribution of O. paralithodis, may generally overlap the native range of its host, $P$. camtschaticus although it is apparently absent over some large areas such as Bristol Bay and Norton Sound, Alaska. The red king crab was intentionally introduced into the Barents Sea, northern Europe, from the northern Pacific in 1961-1969 (Orlov and Ivanov 1978), and its distribution now extends westward beyond the Kola Peninsula to the Norwegian coast (FalkPetersen et al. 2011) and north to the Svalbard archipelago (Kirby 2003). Surveys of the introduced Atlantic population of $P$. camtschaticus for epifauna and parasites 


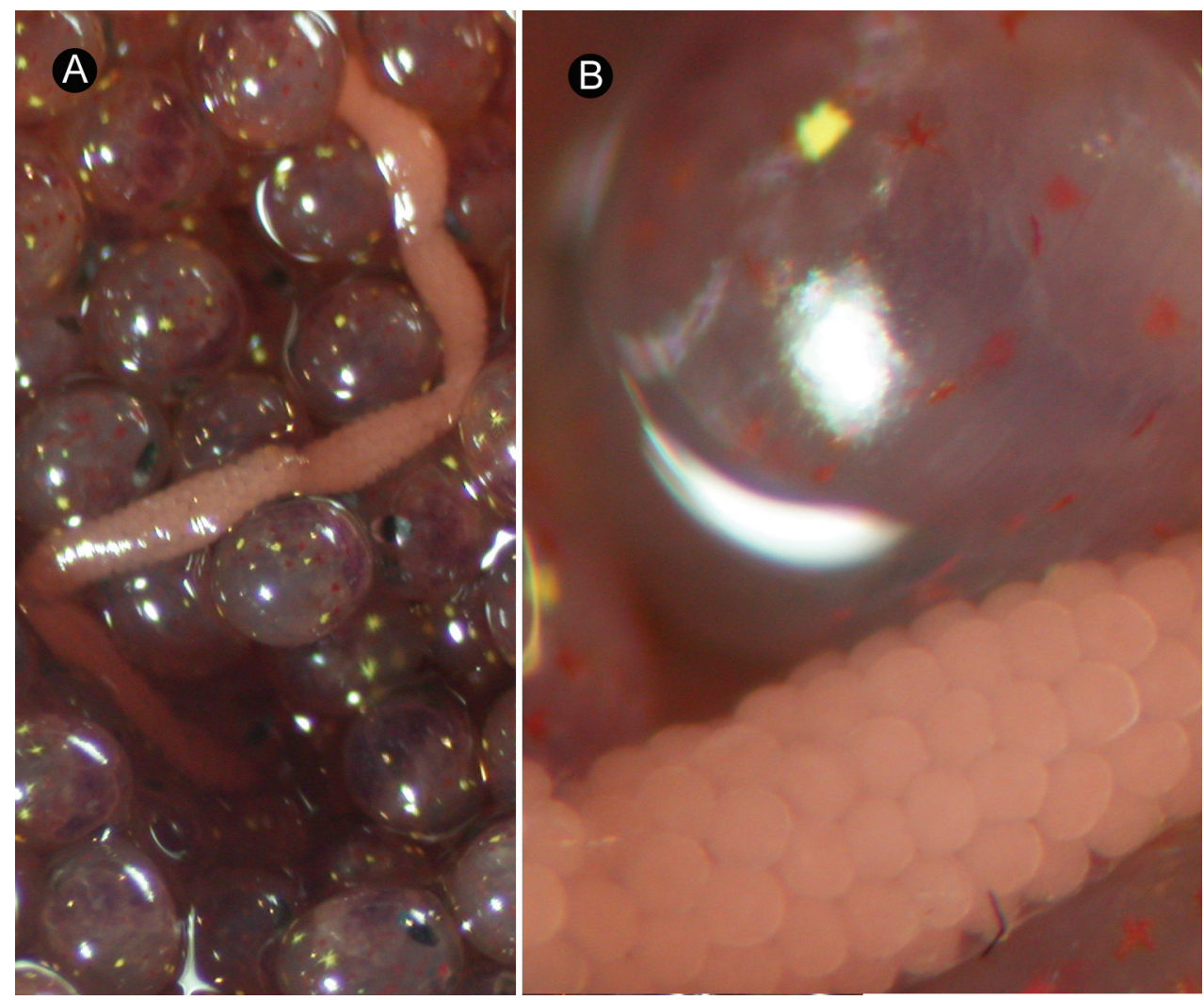

Figure 5. Ovicides paralithodis sp. n. A egg strand laid by holotype $\mathbf{B}$ magnification of $\mathbf{A}$.

have not recovered any symbiotic egg predator nemerteans (Dvoretsky and Dvoretsky 2010, Falk-Petersen et al. 2011). Apparently the introduced crabs were not infested with these important natural enemies. This lack of infectious natural enemies may contribute to their rapid population growth and geographic expansion in the northeastern Atlantic Ocean (Torchin et al. 2003, Falk-Petersen et al. 2011).

Taxonomic remarks. Of the four currently recognised congeners in Ovicides, $O$. paralithodis is distinguished from $O$. julieae and $O$. davidi by the absence of eyes. Ovicides jasoni and $O$. jonesi are eye-less as is the new species. Ovicides jasoni can be distinguished from $O$. paralithodis in having densely arranged submuscular glands (Shields and Segonzac 2007, fig. 3E). Ovicides jonesi differs from the new species in that it lacks vacuolated glandular lobes in the precerebral region (Shields and Segonzac 2007, fig. 6B-D). The new species differs from $O$. julieae also in that the lateral vessels fuse above the oesophagus (seemingly postcerebrally, cf. Shields 2001, fig. 1) in the latter, while $O$. paralithodis has a pair of precerebral cephalic vessels, which meet above the rhynchodaeum, posteriorly passing through the cerebral ring. The markedly different habitats of the hosts (hydrothermal vents and tropical coral reef for the previously described species of Ovicides versus boreal continental shelf waters for $O$. paralithodis) and the very different types of hosts (brachyuran crabs versus an anomuran) add to the 
distinctive nature of the present species. The dorsal position of the ovarian pore in $O$. paralithodis seems to be unique in Carcinonemertidae.

Ovicides paralithodis has only been confirmed from P. camtschaticus. However, a similar eyeless form with accessory stylet pouches is common on tanner crab, Chionoecetes bairdi Rathbun, 1924 and has also been found on the Dungeness crab, Cancer magister Dana, 1852 in Alaskan waters (AMK, unpublished observations).

Molecular phylogeny. In the maximum-likelihood tree $(\ln \mathrm{L}=-9804.30)$ (Fig. 6), O. paralithodis appeared as a sister taxon to the clade comprised of C. carcinophila (Kölliker, 1845) of Andrade et al. (2012) and C. cf. c. imminuta Humes, 1942 of Thollesson and Norenburg (2003). The clade comprised of these three species (family Carcinonemertidae) was supported by $100 \%$ bootstrap value.

\section{Discussion}

One may infer from the present tree topology that the acquisition of Takakura's duct and the loss of cerebral organs occurred in the common ancestor of the family, prior to the loss of accessory stylet pouches or stylets, which happened only in the lineage lead-

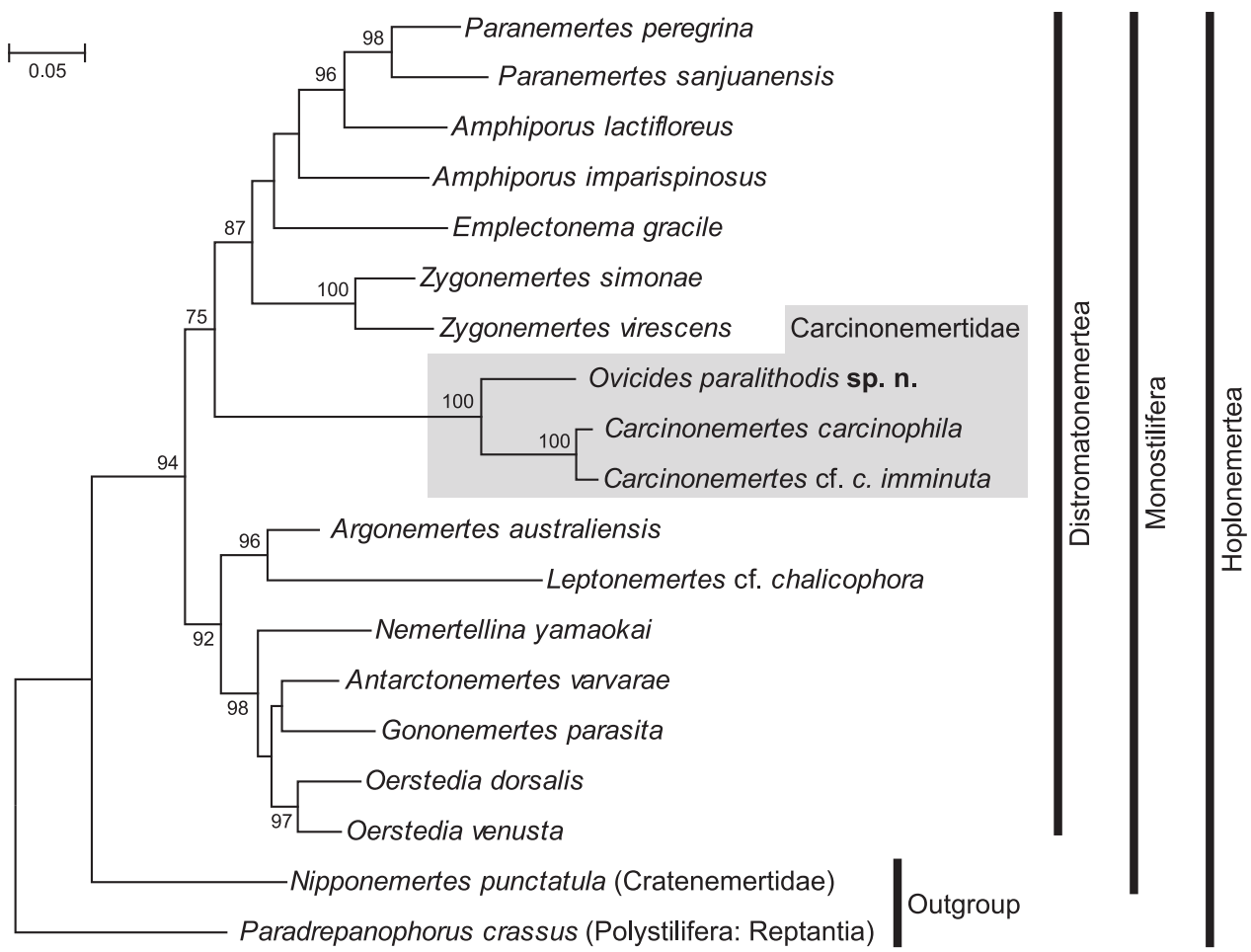

Figure 6. Phylogenetic tree resulting from maximum likelihood analysis of combined $28 \mathrm{~S}$ rRNA and COI $(\ln \mathrm{L}=-9804.30)$. Numbers above/below nodes indicate bootstrap support values $>50 \%$. 
ing to Carcinonemertes, but not in Ovicides. We conclude so because 1) Takakura's duct is possessed by all carcinonemertids, and is otherwise unique in the phylum, 2) with a few exceptions, monostiliferans generally possess cerebral organs, and 3) accessory stylets and their pouches are widespread features among Hoplonemertea, including Ovicides, but are absent in Carcinonemertes. An implication of this character-evolution scenario is that the genus Ovicides, currently diagnosed as a nemertean egg predator having accessory stylets (a plesiomorphy for Carcinonemertidae), may not be monophyletic.

This study supports monophyly of Carcinonemertidae, in agreement with the views of Wickham and Kuris (1988) and Shields et al. (1989). In addition to the characters commonly found among carcinonemertids such as the absence of cerebral organs or the presence of Takakura's duct, Humes' (1942) original diagnosis of the family also included 1) one central stylet, 2) no accessory stylet pouches or stylets, 3) anterior proboscis chamber small and non-glandular, and 4) excretory apparatus absent. Wickham and Kuris (1988) pointed out a necessity to loosen the familial diagnosis, because their Form 4, herein described as $O$. paralithodis, did possess accessory stylet pouches (and accessory stylets) and Takakura's duct. Upon the discoveries of the excretory system in C. regicides and C. epialti Coe, 1902, as well as the large anterior proboscis chamber in $C$. regicides, Shields et al. (1989) emended the diagnosis by removing the abovementioned four characters about stylets, anterior proboscis chamber, and excretory system. Shields et al. (1989) regarded the following five characters as diagnostic for the family: 1) symbiotic relationship with a decapod crustacean, 2) short proboscis, 3) absence of cerebral organs, 4) presence of Takakura's duct, and 5) a "rhabdocoel-like" [sic] hoplonemertean larva [i.e., planuliform larva]. But for the last character, which is not ascertained in Ovicides, all of these apply to O. paralithodis. Presence of Takakura's duct, however, is not confirmed in any other congeners, because no adults are known for O. davidi, O. jasoni, and O. jonesi (Shields and Segonzac 2007); as to O. julieae, which is a simultaneous hermaphrodite, Shields (2001: 305) stated that "Takakura's duct may be present but not observed".

The sister-taxon relationship of Carcinonemertidae among Monostilifera remains uncertain, although the search for it would have a fundamental significance in divergence-time estimates within the phylum. So far, all the carcinonemertids are symbiotic egg predators of Achelata, Anomura, and Brachyura (Jensen and Sadeghian 2005), suggesting that the ancestors of Carcinonemertidae acquired their egg-predatory life style after the host reptantic decapods split from other pleocyemates (i.e., Caridea and Stenopodidea, after Bracken et al. 2009). Fossil records indicate that a radiation of decapods occurred in Triassic-Jurassic (Schram and Dixon 2004). Therefore, carcinonemertids may also have radiated in this period at the earliest.

The position of Carcinonemertidae is likely to be susceptible to long-branch attraction. Carcinonemertes cf. carcinophila imminuta appeared as sister to all the rest of Distromatonemertea included in the analysis by Thollesson and Norenburg (2003). On the other hand, Andrade et al. (2012) showed the phylogenetic position of $C$. carcinophila was method-sensitive, being either the sister to Distromatonemertea (in direct optimization method) or nested among Distromatonemertea (in maximum like- 
lihood and Bayesian analysis), with low nodal support values in both cases. In the present analysis, Carcinonemertidae was nested among Distromatonemertea, appearing to be more closely related to Amphiporus than to Oerstedia (Fig. 6).

\section{Acknowledgements}

We thank Yuji Yoshida (Abashiri Fisheries Cooperative), Taka-aki Watanabe (Department of Fisheries, Ports, and Harbours, Abashiri City), and Ryoichi Tamura (Mariculture Fisheries Research Institute, Fisheries Research Department, Hokkaido Research Organization) for their kind arrangement for the collection of crab specimens. HK also thanks the staffs at the Abashiri Fisheries Science Centre for providing laboratory facilities and Hiroshi Yamasaki (Hokkaido University) for his help in molecular analyses. This study was financially supported in part by Grants-in-Aid for Regional R\&D Proposal-Based Program from Northern Advancement Centre for Science \& Technology of Hokkaido, Japan (\#T-3-22) and Grant-in-Aid for Scientific Research (B) from the Japan Society for the Promotion of Science (\#23370038) for HK, and by the University of California Sea Grant Program under grant NA80AAD-00120 for AMK.

\section{References}

Abildgaard PC (1806) Planaria dorsalis. In: Müller OF (Ed.) Zoologia Danica seu animalium Daniae et Norvegiae rariorum ac minus notorum descriptiones et historia. N. Christensen, Copenhagen (Havnia), 25.

Akaike H (1974) A new look at the statistical model identification. IEEE Transactions on Automatic Control 19: 716-723. doi: 10.1109/TAC.1974.1100705

Andrade SCS, Strand M, Schwartz M, Chen H, Kajihara H, von Döhren J, Sun S, Junoy J, Thiel M, Norenburg JL, Turbeville JM, Giribet G, Sundberg P (2012) Disentangling ribbon worm relationships: multi-locus analysis supports traditional classification of the phylum Nemertea. Cladistics 28: 141-159. doi: 10.1111/j.1096-0031.2011.00376.x

Bergendal D (1900) Über ein Paar sehr eigenthümliche nordische Nemertinen. Zoologischer Anzeiger 23: 313-328.

Bracken HD, Toon A, Felder DL, Martin JW, Finley M, Rasmussen J, Palero F, Crandall KA (2009) The decapod tree of life: compiling the data and moving toward a consensus of decapod evolution. Arthropod Systematics and Phylogeny 67(1): 99-116.

Coe WR (1901) Papers from the Harriman Alaska Expedition. XX. The nemerteans. Proceedings of the Washington Academy of Sciences 3: 1-110.

Coe WR (1902) The nemertean parasites of crabs. American Naturalist 36: 431-450. doi: $10.1086 / 278150$

Coe WR (1905) Nemerteans of the west and northwest coasts of America. Bulletin of the Museum of Comparative Zoölogy at Harvard College 47: 1-318. 
Corrêa DD (1961) Nemerteans from Florida and Virgin Islands. Bulletin of Marine Science of the Gulf and Caribbean 11: 1-44.

Dana JD (1852) Conspectus Crustaceorum, \&c. Conspectus of the Crustacea of the Exploring Expedition under Capt. Wilkes, U.S.N., including the Crustacea Cancroidea and Corystoidea. Proceedings of the Academy of Natural Sciences of Philadelphia 6(3): 73-86. http:// ia700700.us.archive.org/19/items/conspectuscrusta00dana/conspectuscrusta00dana.pdf

Dendy A (1892) On an Australian land nemertine (Geonemertes australiensis, n. sp.). Proceedings of the Royal Society of Victoria 4: 85-122.

Dvoretsky AG, Dvoretsky VG (2010) Epifauna associated with an introduced crab in the Barents Sea: a 5-year study. ICES Journal of Marine Science 67(2): 204-214. doi: 10.1093/ icesjms/fsp243

Edgar RC (2004a) MUSCLE: multiple sequence alignment with high accuracy and high throughput. Nucleic Acids Research 32(5): 1792-1797. doi: 10.1093/nar/gkh340

Edgar RC (2004b) MUSCLE: a multiple sequence alignment method with reduced time and space complexity. BMC Bioinformatics 5: 113. doi: 10.1186/1471-2105-5-113

Falk-Petersen J, Renaud P, Anisimova N (2011) Establishment and ecosystem effects on the alien invasive red king crab (Paralithodes camtschaticus) in the Barents Sea-a review. ICES Journal of Marine Science 68(3): 479-488. doi: 10.1093/icesjms/fsq192

Felsenstein J (1985) Confidence limits on phylogenies: an approach using the bootstrap. Evolution 39: 783-791. doi: 10.2307/2408678

Fleming LC, Gibson R (1981) A new genus and species of monostiliferous hoplonemerteans, ectohabitant on lobsters. Journal of Experimental Marine Biology and Ecology 52: 79-93. doi: 10.1016/0022-0981(81)90172-6

Gibson R, Wickham DE, Kuris AM (1990) A new genus and species of monostiliferoidean nemertean (Nemertea: Enopla) found on an egg mass of the anomuran decapod Paralithodes camtschatica. Zoological Journal of the Linnean Society 98: 185-198. doi: 10.1111/ j.1096-3642.1990.tb01215.x

Graff L von (1879) Geonemertes chalicophora, eine neue Landnemertine. Morphologisches Jahrbuch 5: 430-449.

Griffin BB (1898) Description of some marine nemerteans of Puget Sound and Alaska. Annals of the New York Academy of Sciences 11: 193-217. doi: 10.1111/j.1749-6632.1898. tb54969.x

Humes AG (1942) The morphology, taxonomy, and bionomics of the nemertean genus Carcinonemertes. Illinois Biological Monographs 18(4): 1-105.

Iwata F (1954) The fauna of Akkeshi Bay. XX. Nemertini in Hokkaido. Journal of the Faculty of Science, Hokkaido University, Series 6, Zoology 12: 1-39.

Jensen K, Sadeghian PS (2005) Nemertea (ribbon worms). In: Rohde K (Ed.) Marine Parasitology. SCIRO publishing, Collingwood, 205-210.

Johnston G (1837) Miscellanea Zoologica. II. A description of some planarian worms. Magazine of Zoology and Botany 1: 529-538.

Kajihara H, Gibson R, Mawatari SF (2000) Redescription and taxonomic reassessment of Nemertellina minuta Friedrich, 1935 sensu Yamaoka, 1940 (Nemertea, Hoplonemertea, Monostilifera). Zoological Science 17: 265-276. doi: 10.2108/zsj.17.265 
Kajihara H, Olympia M, Kobayashi N, Katoh T, Chen H, Strand M, Sundberg P (2011a) Systematics and phylogeny of the hoplonemertean genus Diplomma (Nemertea) based on molecular and morphological evidence. Zoological Journal of the Linnean Society 161: 695-722. doi: 10.1111/j.1096-3642.2010.00650.x

Kajihara H, Yamasaki H, Andrade SCS (2011b) Carinoma hamanako sp. n. (Nemertea: Palaeonemertea), the first representative of the genus from the Northwest Pacific. Species Diversity 16: 149-165.

Kirby A (2003) BBC News: King crabs march towards the Pole. http://news.bbc.co.uk/2/hi/ science/nature/3149782.stm

Kölliker A (1845) Drei neue Gattungen von Würmern. Verhandlungen der Schweizerischen Naturforschenden Gesellschaft bei ihrer versammlung zu Chur 29: 86-98.

Kuris AM (1993) Life cycles of nemerteans that are symbiotic egg predators of decapod Crustacea: adaptations to host life histories. Hydrobiologia 266: 1-14. doi: 10.1007/BF00013355

Kuris AM, Blau SF, Paul AJ, Shields JD, Wickham DE (1991) Infestation by brood symbionts and their impact on egg mortality of the red king crab, Paralithodes camtschatica, in Alaska: geographic and temporal variation. Canadian Journal of Fisheries and Aquatic Sciences 48: 559-568. doi: 10.1139/f91-071

Orlov TI, Ivanov BG (1978) On the introduction of the Kamchatka king crab Paralithodes camtschatica (Decapoda: Anomura: Lithodidae) into the Barents Sea. Marine Biology 48: 373-375. doi: 10.1007/BF00391642

Quatrefages A de (1846) Études sur les types inférieurs de l'embranchement des annelés. Mémoire sur la famille des Némertiens (Nemertea). Annales des Sciences Naturelles, Série 3, Zoologie 6: 173-303.

Rathbun MJ (1924) New species and subspecies of spider crabs. Proceedings of the United States National Museum 64(2504): 1-5. http://hdl.handle.net/10088/15298, doi: $10.5479 /$ si.00963801.2504

Sadeghian PS, Santos C (2010) Two new species of Carcinonemertes (Hoplonemertea: Carcinonemertidae) living in association with leucosiid crabs from California and Tasmania. Journal of Natural History 44(37-40): 2395-2409. doi: 10.1080/00222933.2010.505014

Schram FR, Dixon CJ (2004) Decapod phylogeny: addition of fossil evidence to a robust morphological cladistic data set. Bulletin of the Mizunami Fossil Museum 31: 1-19.

Shields JD (2001) Ovicides julieae n. gen., n. sp. (Nemertea: Carcinonemertidae) on xanthid crabs from the Great Barrier Reef, Australia. Journal of Crustacean Biology 21(1): 304 312. doi: 10.1651/0278-0372(2001)021[0304:OJNGNS]2.0.CO;2

Shields JD, Segonzac M (2007) New nemertean worms (Carcinonemertidae) on bythograeid crabs (Decapoda: Brachyura) from Pacific hydrothermal vent sites. Journal of Crustacean Biology 27(4): 681-692. doi: 10.1651/S-2794.1

Shields JD, Wickham DE, Kuris AM (1989) Carcinonemertes regicides n. sp. (Nemertea), a symbiotic egg predator from the red king crab, Paralithodes camtschatica (Decapoda: Anomura), in Alaska. Canadian Journal of Zoology 67(4): 923-930. doi: 10.1139/z89-134

Stricker SA (1982) The morphology of Paranemertes sanjuanensis sp. n. (Nemertea, Monostilifera) from Washington, USA. Zoologica Scripta 11: 107-115. doi: 10.1111/j.14636409.1982.tb00523.x 
Tamura K, Peterson D, Peterson N, Stecher G, Nei M, Kumar S (2011) MEGA 5: molecular evolutionary genetics analysis using maximum likelihood, evolutionary distance, and maximum parsimony methods. Molecular Biology and Evolution 28: 2731-2739. doi: $10.1093 / \mathrm{molbev} / \mathrm{msr} 121$

Tavaré S (1986) Some probabilistic and statistical problems in the analysis of DNA sequences. In: Miura EM (Ed.) Some Mathematical Questions in Biology_DNA Sequence Analysis. American Mathematical Society, Providence, Rhode Island, 57-86.

Thollesson M, Norenburg JL (2003) Ribbon worm relationships: a phylogeny of the phylum Nemertea. Proceedings of the Royal Society B 270: 407-415. doi: 10.1098/rspb.2002.2254

Tilesius WC (1815) De Cancris Camtschaticis, Oniscis, Entomostracis et Cancellis marinis microscopicis noctilucentibus, Cum tabulis IV: Aenacis et appendice adnexo de acaris et Ricinis Camtschaticis. Auctore Tilesio. Conventui exhibuit die 3 Februarii 1813. Mémoires de l'Académie Impériale de Science de St. Pétersbourg 5: 331-405.

Torchin ME, Lafferty KD, Dobson AP, McKenzie VJ, Kuris AM (2003) Introduced species and their missing parasites. Nature 421: 628-631. doi: 10.1038/nature01346

Verrill AE (1879) Notice of recent additions to the marine Invertebrata, of the northeastern coast of America, with descriptions of new genera and species and critical remarks on others. Part I-Annelida, Gephyraea, Nemertina, Nematoda, Polyzoa, Tunicata, Mollusca, Anthozoa, Echinodermata, Porifera. Proceedings of the United States National Museum 2: 165-205. doi: 10.5479/si.00963801.76.165

Wickham DE (1978) A new species of Carcinonemertes (Nemertea: Carcinonemertidae) with notes on the genus from the Pacific coast. Proceedings of the Biological Society of Washington 91: 197-202.

Wickham DE, Kuris AM (1985) The comparative ecology of nemertean egg predators. American Zoologist 25: 127-134.

Wickham DE, Kuris AM (1988) Diversity among nemertean egg predators of decapod crustaceans. Hydrobiologia 156: 23-30. doi: 10.1007/BF00027974

Wickham DE, Roe P, Kuris AM (1984) Transfer of nemertean egg predators during host molting and copulation. Biological Bulletin 167: 331-338. doi: 10.2307/1541280 